DOI: 10.1515/linpo-2015-0008

\title{
Inflection - semantics interfaces in a typological setting: number and non-specific nominal items in Old Spanish legal codices
}

\author{
Mikołaj Nkollo \& Magdalena Tkaczyk
}

AMU Institute of Romance Studies, Poznań

mikon74@amu.edu.pl,magdat@amu.edu.pl

\begin{abstract}
Mikołaj Nkollo \& Magdalena Tkaczyk. Inflection - semantics interfaces in a typological setting: number and non-specific nominal items in Old Spanish legal codices. The Poznań Society for the Advancement of Arts and Sciences, PL ISSN 0079-4740, pp. 17-29

The present inquiry has been spurred by the observation of the morphological behaviour of humandenoting common nouns in Old Spanish codices (13th to 15th century). In spite of the fact that legal norms are designed to apply to an unrestricted number of potential addressees, this class of nominal items surfaces nearly exclusively in the singular, with plural forms being strongly underrepresented. A series of parameters converge to account for this form - function mismatch, thus revealing an essentially interdependent nature of linguistic mechanisms underlying it: type of inflection (inherent vs. contextual), text genre characteristics (distance pole vs proximate pole) and syntactic environment (conditional protases). The pervasiveness of the singular is traced back to non-specificity. Out of two mutually exclusive typological clines accounting for the likelihood of inflectional variation in noun morphology, Definiteness Hierarchy is given preference over degrees of animacy: non-specifically used items, even if highly ranked on animacy scale, are the least likely to surface as plural forms. Competing motivations are assumed to provide a suitable analytical framework to account for typological conflicts such as the one exemplified in Old Spanish legal codices.
\end{abstract}

Keywords: non-specific NPs, distance pole texts, si-clauses, Animacy Hierarchy, Definiteness Hierarchy, competing motivations

\section{Introduction: inflection-semantics mismatches}

A closer inspection of human-denoting common nouns in Old Spanish legal codices reveals that some of them surface nearly exclusively in the singular, while their plural forms are seriously underrepresented. The imbalance between the two inflectional features is so strong that the paradigms of some of these nouns look as if they were virtually reduced to the singular. For example, in the Fuero Viejo de Alcalá, the oldest of the source texts analysed in the present paper (13th century), out of 70 attestations of the forms for the lexeme 'woman' (with different spelling variants), 37 occurrences of muger (singular), 1 of 
mugeres (plural), 27 of mulier (singular), 2 mvger (singular) and 3 of mvlier (singular) have been retrieved. Curiously, occurrences of the plural are scarce in defiance of a potentially unrestricted number of addressees of legal regulations (see items in plain characters in the preamble to the Fuero Real quoted below). Thus, the main research problem is: Why is the singular pervasive and the plural virtually non-existing?

The aim of the present paper is to come up with a consistent typological account of the ubiquity of such inflection - meaning mismatches in Old Spanish (henceforth, OS). This property of medieval Spanish noun morphology will be presented from the so-called 'interface' perspective on inflection: paradigmatic properties of specified groups of expressions are viewed in conjunction with phenomena belonging to other levels of linguistic analysis. Such a methodological step is deemed necessary. In fact, most of OS human-denoting nouns are assumed to have out-and-out regular paradigms. In the remaining types of texts, both of their number values are equally (though not always evenly) present. That is why the term 'mismatch' has been chosen to identify the phenomenon under discussion.

\footnotetext{
La ley ama \& ensenna las cosas que son de dios \& es fuente \& de ensenamiento. \& maestra de derecho \& de iusticia. \& ordenamiento de buenas costumbres et guardamiento de pueblo \& de su uida. \& es tam bien pora las mugieres como pora los uarones. tan bien pora los mancebos como pora los uieios. Tan bien pora los sabios como pora los non sabios. assi pora los dela cibdat. como pora los de fuera \& es guarda del rey \& de los pueblos. [Fuero Real, 1255, fol. 8v-9r]

'The law fosters and teaches divine matters; it is a perfect example of mastery of justice, righteousness and the arrangement of virtuous habits, thereby establishing guidelines and providing assistance to the life of common people, that is for the sake of women, as well as for men, for adolescents and the elderly, for the wise and for the uncultured ones, and both for the sake of those who live in towns and those who live outside, so as to constitute a safeguard to protect the king and the people'.
}

The first hypothesis on how such mismatches arise is that the recurrent use of the singular must be traced back to the quantifying force of nominal items in legal codices. The overarching dichotomy involves specific vs. non-specific readings, on a par with a bundle of concurrent parameters: presupposition of existence (or its absence), as well as the unique identifiability of the referent (Haspelmath 1997: 38). Moreover, the diagnosis of the dominance of the singular will be couched in terms of the interplay of two concepts frequently evoked in typological analyses: the Animacy Hierarchy and the Definiteness Hierarchy.

The paper is organized as follows: in section 2 empirical data are characterized. Then, in section 3, the focus placed on codices is motivated in terms of the differences between so-called 'proximate pole' and 'distance pole' texts, thus providing the first of a series of clustering non-morphological factors responsible for the distribution of number values over OS common nouns. Furthermore, si-conditionals, which represent the most frequent syntactic environment for this class of linguistic signs, are described. Their analysis is conducted in terms of the epistemic links relating the content of protases to the speaker's assessment of how things happen to be in the world. The last criterion makes an extensive use of the distinction between so-called inherent and contextual morphosyntactic features. Section 4 discusses the variety of NPs found in OS legal texts. In spite of some formal diversity, the singular appears throughout. It might, then, be hypothesized that neither referential nor inflectional properties of NPs are systematically matched by the type of their determiners. Moreover, in accordance with the principles of 'competing motivations' framework, inflection - meaning mismatches are approached in terms of the interplay of two typological pat- 
terns: the Animacy Hierarchy and the Definiteness Hierarchy. Their relevance to the present discussion results from the fact that they account for the likelihood of inflectional variation in different types of NPs. Finally, the interdependent nature of the observed phenomena is highlighted in the closing section.

The disproportionate number of occurrences of the singular at the expense of the plural is a problem of detail, which is of a far-reaching theoretical significance. In a broader perspective, the present study revolves around morphological phenomena falling within the scope of other levels of linguistic analysis. The usefulness of an interface-based approach relies crucially on the assumption of the modular structure of the mind in general and of the human language capacity in particular (cf. Labelle 2001: 157-158, 162). If a theory assumes a separate morphological module, then this will be situated almost always in the centre of the linguistic model and, thus, will have direct and non-trivial ties to all other modules (O'Grady 2011: 63). It is argued here that the understanding of the inflectional behaviour of common nouns denoting human beings in OS legal texts can be achieved only with the aid of numerous linguistic modules and their interaction.

\section{The characterization of data}

Examples have been retrieved from texts available in the Hispanic Seminary of Medieval Studies - Digital Library of Old Spanish Texts. Spanish Legal Texts database. Data drawn from medieval manuscripts underwent a careful philological processing (e.g. some of the omitted parts of words have been restored, basic punctuation marks have been added) so as to be readable by large audiences. The texts for the present paper ${ }^{1}$ were randomly selected, so as to encompass three centuries, owing to which the persistence of the inflectional phenomena under discussion is evidenced. Yet, our analysis is neither concerned with the structural shifts which occurred in the Spanish morphosyntax, nor with the original traits recordable in various regional varieties. In spite of the differences in size, all the sources enumerated above are treated jointly. Likewise, regardless of the variety of themes raised in some of them (mainly the Fuero Real), they exhibit an astonishing stylistic homogeneity, at least as far as purely legal sections are concerned. Importantly, stylistic unity has a bearing on which grammatical structures are prevailing. As their authors intended to put in correspondence potential infringements and sanctions, si-conditionals are one among the most recurrent types of sentences in these codices.

For the analysis to be conducted on even more rigorously circumscribed material, further constraints are going to be introduced: (i) unless indicated otherwise, conditional protases are the only structures taken into account. If two or more of them are coordinated or juxtaposed, the second clause habitually abounds in anaphorically bound items (e.g. an

1 The following writings were subject to analysis: Leyes del estilo (abbrev. LE, 1301-1400, Madrid: Nacional, MSS/5764; 41,207 word tokens), Fuero de Briviesca (abbrev. FB, 1350-1450; 73,625), Fuero de Navarra, versión A (abbrev. FN-A, 1340-1341; 80,061), Fuero General de Navarra (abbrev. FGN, 1330; 87,557), Fuero de Salamanca (abbrev. FS, 1301-1400; 19,420), Fueros de Castiella (abbrev. FC, 1301-1400; 79,556), Fuero Real (abbrev. FR, 1301-1400; 54,749), Fuero Juzgo (abbrev. FJ, 1260-1300; 99,118) Fuero Viejo de Alcalá (abbrev. $F V A, 1223 ; 22,474)$. The dates in brackets indicate when the manuscripts (not the original codices) serving as the source of concordances and transcriptions available in the HSMS corpus were compiled. 
increased presence of nouns determined by demonstratives and possessives, object-personal pronouns alongside null subjects; see 1a-b). The characteristics of such 'second-hand' protases depart in a number of ways from the ones containing common nouns. To prevent their morphological description from being distorted, preference is given to the first protasis in a series of protases; (ii) the clauses subject to analysis are required to contain common nouns denoting humans. Proper names are disregarded altogether. Likewise, if entities other than human beings are dealt with in conditional sentences, their names are omitted (see 2a); (iii) despite sharing a deontic flavour or being otherwise semantically related to conditional sentences, other constructions with common nouns are left out of the analysis. They include: temporal clauses introduced by quando (3a), universally quantified NPs, restricted by a relative or a temporal clause $(3 \mathrm{~b}-\mathrm{c})$, sentences headed by the relative pronoun quien with no antecedent (cf. 3d-e), and clauses containing a bare noun restricted by a relative clause (3f). Elements highlighted in the examples below illustrate what has been left out of the discussion. English translations are ours.

(1a) Et sy alguno dellos quisiere mal fazer al otro. $\boldsymbol{O}$ deue ante dessafiar \& de terçer dia en adelante puedel desonrrar. [FC, fol 64r]

'And if either of them intends to cause harm to the other, he has, first, to mount a challenge and, from the third day on, he is allowed to put shame on him'

(1b) Si omne soltero con mugier soltera fiziere fijos \& despues $\boldsymbol{O}$ casar con ella ... [FR, fol 57v] 'If an unmarried man begets children with an unmarried woman and gets married with her thereafter ...'

(2a) Todo omne que conprar liebres \& coneios o perdiçes o pescado reziente o ferren o yerua o lana pora revender o mesura mala touier peche .ij. morauedis \& pierda la mercadura [FS, fol 35r]

'Everyone who buys rabbits, hares, partridges or fresh fish or herbs or wool in order to resell it or has scales giving false results, is liable to fine of two maravedí and should lose their goods'

(3a) Quando dos omnes pelearen \& el uno quisiere ferir al otro. Et por ocasion matare a otro omne alguno: el alcalle deue saber qual dellos boluio la pelea [FB, fol 90r]

'When two men quarrel and one of them wants to hit the other and, by chance, another man happens to be killed, the alcalde must find out which of them started the brawl'

(3b) Ningun clerigo benefiçiado de eglesia o que sea ordenado [...]. non tenga uoz de njnguno antel alcalle. sin mandado del Rey [FB, fol. 11v]

'No cleric, be he entitled by the Church or ordained, is allowed to have a voice before the alcalde without the consent of the King'

(3c) Esto es por fuero de todo omne que alloga bestia a otro omne \& gela alloga fasta logar nombrado ... $[F C$, fol 46v]

'The fuero orders that every man who loans a beast to the other man and does so under specified conditions ...'

(3d) Qvi a sabiendas quema casa en villa. deuenlo quemar por ende. \& delos bienes del deuen entregar al dueno del precio dela casa [FJ, 93v]

'The one who sets fire on purpose to a house in the town should be burnt for that and his goods should be handed over to the owner so as to make up for the price of the house'

(3e) Qvien mete labrador en su tierra si por uentura aquel que tomo la tierra diere la tercia parte dela tierra a otri que la labre. pague cada uno dellos la renda de la tierra segundo la partida que tiene dela tierra $[F J$, $84 \mathrm{v}]$

'The one who lets out his plot of land to a farmer, if it happens that the tenant sublets the third part of the land to another farmer who cultivates it, a rental commensurate with their slice of land must be paid by each of them'

(3f) Njn omne nin mugier que se maluar de Salamanca o de su termino sus parientes mas propinquos prendan su auer a proy de sus fijos si los ouier [FS, 51r]

'The closest relatives of a man or a woman who can be guilty of misconduct in Salamanca or in its outskirts should be entitled to take hold of their belongings for the benefit of their children, if they have any' 


\section{Morphology and contributing factors}

As for more properly linguistic criteria relevant to the aim pursued here, the first relies on the assumption that particular text genres and inflectional properties of common nouns are interlinked. This linkage is mediated via the quantificational status of NPs. Nowadays, the relationship between text characteristics and the specific vs. non-specific dichotomy is taken for granted (Koch \& Oesterreicher 2011: 135, 138, 148-151). Likewise, the selection of number value is assumed to be sensitive to the specific vs. non-specific divide.

Various text genres are frequently depicted as points scattered along a cline leading from the proximate to the distance pole (Koch \& Oesterreicher 2001: 586-588). The latter comprises texts designed to be communicated in public and in planned communicative acts. They usually have unknown addressees and display a minimal emotional involvement. In such texts, non-specifically used NPs are reported to outnumber nouns which have their full-fledged referents. This characteristic is known to go hand in hand with the tendency to express timeless states of affairs and universal truths (Topolińska 1977: 64-66). The very nature of the $s i$-clauses in legal codices consists in formulating premises enabling languageusers to issue universal deontic judgements which are conceived of as taking place at no particular moment or time interval. Conversely, in more subjective narratives forming a dramatic plot, preference is given to specifically used nouns. Their presence is tied with the following characteristics: intimate and spontaneous communication, known addressees, and strong emotional load (Lindschouw 2013: 126-127).

The example given below shows a more balanced interplay of singular and plural forms in proximate pole texts. It has been drawn from one of the most renowned medieval Spanish epic poems (composed at the end of the 12th or in the early 13th century) - El Cantar de mio Cid, where heroic deeds of particular warriors and their family' members are reported. The events that make up the plot nearly always have a clear-cut temporal anchorage. Two randomly selected samples were subject to analysis. The count involved all successive occurrences of human-denoting nouns from two loci: verses 1512 to 1715 (folios $31 \mathrm{v}$ to 35r) and verses 3480 to 3735 (folios $69 \mathrm{v}$ to $74 \mathrm{r}$ ). In both cases, regardless of their high frequency, proper names (surfacing nearly exclusively in the singular) were omitted. The results reveal a surprisingly high ratio of plural to singular forms. Curiously, in the first segment, the number of plural forms exceeds the number of those in the singular (out of 80 tokens of humandenoting common nouns, 42 , i.e. $52.5 \%$ represent the plural). In the second, the number of singular forms is hardly superior to their plural counterparts (the exact ratio is 49:42, i.e. $53.8 \%$ to $46.2 \%$ ). The example below provides an illustration of how such distributional effects are achieved:

(4) O cuemo saliera de castiela albarfanez con estas dueñas que trahe (1512) Los que yuan mesurando e legando lo van delant (1513) Luego toman armas e tomanse a de portar (1514) Por çerca de salon tan grandes gozos van (1515) Don legan los otros a mianya albarfanez se uan homilar (1516) Quando lego auegaluon donta oio ha (1517) Sonrrisando se dela boca hyualo abraçar (1518) Enel ombro lo saluda ca tal es su husaie (1519) Tan buen dia con unosco minaya albarfanez (1520) Traedes estas dueñas poro valdremos mas (1521) Mugier del çid lidiador essus fijas naturales (1522) Ondrar uos hemos todos ca tales la su auze (1523) Mager que mal le queramos non gelo podremos dar (1524) $(31 \mathrm{v}, 1512-1524)^{2}$

2 The following is an almost verbatim line by line translation retrieved from the website of the Liberal Arts ITS (University of Texas, Austin) 'And how he had left Castile Álvar Fáñez with these ladies he brings. (1512) 
All in all, the inflection - meaning equilibrium is habitually restored in proximate pole texts: the referential plural, i.e. corresponding to cardinalities higher than one, is far less frequently represented by singular forms than it is in distance pole texts.

Mismatches in the distribution of number values are viewed here as arising within nonspecific NPs. By no means is the existence of participants in such cases presupposed. Likewise, the indication of their number ceases to be significant (Nkollo \& Wielgosz 2014: 351-352). To put it differently, speakers do not commit themselves as to whether any individuals denoted by common nouns with this quantificational status actually exist nor how many of them there can be. Of all classes of nominal items, the non-specific ones are the least likely to exhibit inflectionally marked number, with the plural being strongly disfavoured. That is why occurrences of common nouns with an inherent plural defy a general tendency of distance pole texts to have their NPs surfacing as singulars. In studies devoted to how particular number forms are cross-linguistically mapped onto particular meanings, the singular is reported to be the default option, i.e. to be better suited to represent numerous entities than the other way round (Dryer 2013). Generic uses are typically adduced as illustrations. This is also the case for common nouns in si-clauses recurrent in OS codices.

The second criterion that helps circumscribe items for our typological inquiry is going to be defined on the basis of structural and semantic properties of sentences hosting humandenoting nouns. As announced in the preceding paragraphs, singular forms introducing multiple participants are ubiquitous after conditional si. Some more fine-tuned distinctions are needed here. First, conditional sentences are not all alike, if seen against the background of epistemic links relating the propositional content of protases to the speaker's appraisal of extra-linguistic reality. As many as three variants need to be singled out here: factual, counterfactual and hypothetical (Schwenter 1999: 11-12). None of them mirrors exactly the status of $s i$-clauses found in OS codices. On the one hand, conditional sentences conjecture about situations that are merely potential - the lawmaker does not take for granted that a given state of affairs, indicated in the protasis, is ever going to take place. Therefore, some of the $s i$-clauses behave as hypothetical judgements. On the other hand, the rationale of all legal regulations is to find consistent solutions to oft-occurring situations, to obviate imminent misbehaviours and to state how, once committed, they should be sanctioned. Therefore, some protases found in such texts exhibit some degree of factuality. The situations envisaged in them are known by hindsight or by received wisdom, etc.

Such a multi-faceted epistemic status of conditional sentences is corroborated to some extent by lexical and grammatical structures accompanying the conditional si. First, OS si-clauses are very frequently embedded within the scope of dezimos que, estabelecemos que or esto est por fuero de 'By virtue of the Fuero of ... (it is the case that if)' (see 5a-b). Given that nominal items tend to be used non-specifically in legal texts, these introductory formulae act as topical elements. Not only do they state that sequentially ordered textual

Those who were scouting and moving forward go ahead, (1513) quickly they take up arms and begin to sport, (1514) over near the Jálon such great joys are sounded. (1515) When the other arrive they go to bow to Minaya Álvar Fáñez, (1516) when Avengalvón arrived, when he is in view, (1517) smiling from his mouth, he was going to embrace him, (1518) on the shoulder he kisses him, for such is his custom, (1519) - Such a good day be with you, Minaya Álvar Fáñez! (1520) You being these ladies for which we will be more worthy, (1521) wife of the Cid and his natural daughters, (1522) all of us will honor you, for such is his fortune, (1523) even if we wish him harm, we won't be able to do him any'. (1524). 
units deal with customary states of affairs. They also ensure some continuity of these units, thus providing an argument in favour of the factual properties of protases.

(5a) Esto es por fuero que sy vn omne demanda a otro omne quel forto aztor o falcon o gauylan o otra aue de caça o podencos \& los fallar los podencos o las aues \& gelo prouare con omnes buennos deuel dar lo suyo $[F C$, fol $69 \mathrm{r}]$

'The fuero orders that if a man asks another man to lend him a hawk, a falcon or an osprey or a hound dog and fails to keep the dogs or the birds, if the loss is proved to him by righteous men, he is bound to give his own [dogs or birds] in exchange'

(5b) Et otrossi dezimos si el pleyto for atal que aquel a quien demandanan non se semeye que auia nenguna culpa. nin fazia ningun tuerto ... [FJ, fol $15 \mathrm{v}]$

'And likewise, we say that if in a lawsuit the defendant denies a charge, or claims that no guilt can be blamed on him ...'

Conversely, hypotheticality, which comes near to the meaning of 'I don't know (whether the state of affairs described in the antecedent is really the case)', is grammatically underpinned by the conjunctive mood (see 6a-b; Squartini 2010: 120-121). All in all, the epistemic status of conditional clauses documented in OS codices displays some features proper to hypotheticals and some proper to factual judgements.

(6a) Et si el sieruo firier a otro sieruo assi como es de suso dicho. el iuyz asme segundo la laga o segundo la sennal. quanto deue pechar el sieruo. o su sennor por el [FJ, fol 58r]

'And if a servant injures another servant in the above-mentioned manner, the judge calculates how much is to be paid by him or by his lord on the basis of wounds or corporal harms'

(6b) Et si algun infançon quoal quiere que sea en estas cosas enuayere o feriere o matare adalgun noble omne de linage ( $F G N$, fol 76r)

'If a young man of whatever chivalric rank invades or injures or kills some nobleman of lineage ...'

Related to the above, but obeying to a slightly different set of criteria, is another trichotomy: conditional constructions are different according to what the speaker is doing in the apodosis. In other words, apodoses vary as to the type of predication. In content conditionals a simple assertion about the external world is produced. The protasis specifies the state of affairs (hypothetical or supposed to be true) enabling speakers to come up with such an assertion. The indicative mood found in some of the si-clauses may be taken to reflect on a formal level the overwhelmingly descriptive character of a given proposition. Its specificity lies in that certain kinds of more or less fortuitous situations are put in correspondence with publicly important consequences (7a-b). By contrast, in speech-act conditionals, some behavioural stance is taken towards the situation communicated in the apodosis. Usually, an order is issued or a particular state of affairs is opted for, which warrants the use of the imperative mood. The protasis shows, then, under what circumstances a given speech act is 'felicitous' (8a-b). Finally, epistemic conditionals appear if an inference, whose symptoms are outlined in the protasis, is drawn by the speaker (Schwenter 1999: 13-15). This type is absent in legal codices. In a nutshell, si-sentences in OS are not homogenous in this respect.

(7a) Esto es por fuero de Castiella que sy vn fijo dalgo baraia con otro fijo dalgo [...] Et sy alguno dellos quisiere mal fazer al otro. deue (3.SG.INDIC.PRES) ante dessafiar \& de terçer dia en adelante puedel (3.SG. INDIC.PRES) desonrrar. [FC, fol 64r]

'The Fuero of Castile orders that if a nobleman quarrels with another nobleman [...] And if either of them intends to cause harm to the other, he must mount a challenge first and from the third day on, he is allowed to put him to shame' 
(7b) SJ fidalgo a otro fidalgo quemare o derribare casas o cortare ujnnaso arboles [...] o le feziere otro mal que non tanga en su cuerpo. maguer que non le aya ante desafiado non es (3.SG.INDIC.PRES) por ende aleuoso. $[\mathrm{FB}$, fol $95 \mathrm{r}]$

'If a nobleman sets fire to another nobleman's house or destroys his winery, cuts down grapes or causes him other non-corporal harm, even if he had been previously sued, he is not declared treacherous for that reason'

(8a) Si algun omne libre. laga otro omne libre. \& aquel que es lagado muere luego. El que lo mata sea penado (3.SG.IMPER.PRES) por el omiziello. [FJ, fol. 58v]

'If a free man causes injuries to another free man and the one who sustained injuries dies thereafter, the man who kills him is to be punished for homicide'

(8b) Mas sy el alcalde les pone plazo para oyr sentençia para dia çierto en el proçesso \& non con jntinçion. njn con mandado del alcalde que se uaya (3.SG.IMPER.PRES) dela corte ( $L E$, fol.73v)

'But if the alcalde sets the deadline for the sentence to be heard by them on a fixed day of the lawsuit, he must not leave the court either intentionally or by the alcalde's order'

Finally, the last prerequisite for an accurate characterization of the above-mentioned morphological imbalance has to do with the distinction between 'inherent inflection' and 'contextual inflection'. In the former a given inflectional feature is chosen in compliance with the speaker's communicative intentions. Instead of being elicited by combinatorial requirements of neighbouring items, inherent features convey information arising within the element in which they are found. Conversely, contextual inflection means that a particular morphological feature appears as a compulsory, syntactically-induced by-product (Booij 1996: 2). Linguistic signs exhibiting contextual features convey information that originates outside of them (Kibort 2010: 68-69). In old Romance languages, features found in controllers of agreement are inherent, while the ones surfacing in agreement targets and in governed items are syntactically-bound.

In conditional sentences documented in OS legal texts, only human-denoting nouns with inherent inflectional features can be said to occur with virtually no plural. This constraint shows that plural forms, such as omnes, mugeres, ninnos, ninnas, etc. must not be dismissed outright, even in legal texts. They do appear, but their presence hinges crucially on syntactic constraints imposed by another element. For example, if it is expressly meant that a given norm applies to a specified number of individuals, a numeral is needed. If its cardinality exceeds one, the numeral triggers agreement and coerces neighbouring nouns into taking the plural, accordingly. The case is conveniently illustrated with bezinos, one of the spelling variants of the plural of vecino 'neighbour, compatriot, mate'. Out of 115 attestations of bezinos in the FVA, only four fail to be accompanied by a numeral (given that they occur outside si-clauses, example 9a for an inherent plural has been retrieved from the Fuero Juzgo; 9b is an instance of contextually-induced inflection)

(9a) Si algun omne a buey brauo o toro. o uaca. o otra animalia mate la luego ante que faga mal. \& si lo sabe por los uezinos quel dizen que es atal [FJ, fol. 73v]

'If any man (finds himself) with an overexcited ox, bull or cow or another animal, he should kill it before any harm is caused, if neighbours warn him how it might be'

(9b) Muger qui dixiere ad otra puta. o rocina. o monaguera. peche i. Morauidi \& iure que lo dixo con sanna \& no lo sabe in ela \& si negare el baron o la muger que no lo dixo firmen con .iijes. bezinos [FVA, fol. 21v] "If a woman addresses another woman as "bitch, or asshole, or trollop", she is bound to pay one maravedí and to swear her words were uttered in wrath and to take them all back \& if a man or a woman denies having said that, they should issue a written statement confirmed by three countrymen'

As for what classes of common nouns depart from the distributional pattern described here, the ratios of inherent to syntactically-induced plurals vary significantly from one text 
to another. Yet, some general tendencies can be easily found. For example, kinship terms (fijos 'children, sons', parientes 'relatives', (h)ermanos 'brothers', nietos 'grandchildren', etc.), on account of their strongly relational meaning, are less reluctant to accept an inherent plural, which is neatly evidenced (10a-b).

(10a) E si alguno deyllos promete fiança alos ermanos o alos parientes en tales casos por fuero la fiança non deuen recebir (FN-A, 53r)

'And if any of them promises pawns to their brothers or to their relatives, in such cases by virtue of the law they must not be given pawns'

(10b) ... otro si de sus bienes faga el lo que quisiere si ningun dellos non ouiere fijos derechos $(F R, 102 \mathrm{v})$

'... likewise, he should have the run of his belongings at his will, if none of them has legitimate sons'

Likewise, an overt, not syntactically-induced, morphological marking is compelling, if ambiguity is to be avoided for administratively vital reasons. In some types of regulations, such as dividing an inheritance (apart from kinship terms, it is herederos 'heirs' that, with its 68 occurrences in the $F R$, outnumbers the 26 tokens of the singular heredero), allotting duties to numerous individuals in a particular order, or exerting parental rights, plural cannot be circumvented. Thus, the morphology - semantics correspondence is sometimes resumed due to lexical factors, even in generically used nouns.

\section{Typological conflicts}

Morphology-semantics mismatches in si-conditionals are fairly puzzling if matched against the diversity of determiners accompanying common nouns. The three most frequent models of NPs in medieval codices are: 1) definite article - noun (11a); 2) bare noun (11b); 3 ) noun preceded or followed by an indefinite element (11c). ${ }^{3}$ Two questions arise at this stage: Does the multiplicity of the textual realizations of NPs in the protases correspond to any semantic differences? How should the pervasiveness of singulars in all of them be explained?

(11a) Et sy el sennor diere cauallo. \& armas. \& loriga a su vasallo con quel sierua puede gela pedir \& el deue gelo dar $[F C, 121 \mathrm{r}]$

'And if the lord gives a horse, weaponry, a suit of armour to his vassal with whom he might be under arms, he is allowed to request them from the vassal, and the vassal is obliged to hand them back to him'

(11b) Et sy cauallero o escudero heredar fijo de barraganna \& dixiere fago te fijo \& heredo te deue heredar en aquella heredat en que el fiziere fijo \& non en mas $[F C, 62 \mathrm{r}]$

'If a knight or a henchman makes his mistress's son a lawful successor and says: "I acknowledge you as my son and I make you my successor", he should take part in that succession to the extent he has been made son, and not more'

(11c) Sy algun fijo dalgo ouyere querella de obispo o de cauallero o de abad o de prior o de comendador o de algunnos del abadengo ... [FC, 13r $]$

'If any nobleman has a quarrel with the bishop, or with the knight, or with the abbot, or with the superior, or with the commander, or with any men of the abbey ...'

3 Controversies over the quantifying force of the indefinites were extensively debated in papers devoted to the structures known as 'donkey sentences'. Their peculiarity lies in that their antecedents (or, sometimes, relative clauses) contain an indefinite item which binds elements (usually personal pronouns) anaphorically in the main clause, as in If everyone likes a donkey, it is happy (Heim 1982: 45-46). Such structures pose a serious challenge to the claim that indefiniteness always entails existential quantification. Rather, indefinites in conditional protases have the status of universal or free-choice elements with no presupposition of existence. 
The hypothesis advocated here is that irrespective of how a given NP is internally configured, in all types of $s i$-clauses documented in OS codices NPs define a class of objects, thus leaving no room for the selection of a particular individual from a set. Their quantifying force has a substitutional character. According to Longobardi (1988), item $x$ is quantified substitutionally if for at least one substitution value of $\mathrm{x}, \mathrm{S}$ (i.e. sentence) is true. This formula eschews cleverly the tricky issue of presupposition of existence. In historical accounts of noun morphology in early Romance languages, instances of generic quantification are habitually associated with bare nouns (Company 1991: 404-405; Penny 2002: 145). Yet, in distance pole texts non-specificity is also conveyed by NPs which look as if they were subject to existential quantification. However, on closer inspection, reference in such cases is only spurious. In point of fact, presupposition of existence is not found in names of participants subject to legal regulations. Summing up, the quantifying force of a given NP once again proves more far-reaching than its syntactic architecture.

The diagnosis of factors responsible for the dominance of the singular at the expense of the plural in OS si-conditionals is going to be reformulated with the aid of two concepts frequently evoked in typological linguistics. The first is the Animacy Hierarchy (henceforth, $\mathrm{AH})$. Its role is to account for how particular number values are distributed according to what kind of entity is denoted by particular types of linguistic signs.

(12) speaker $>$ addressee $>3^{\text {rd }}$ person $>$ kin $>$ human $>$ animate $>$ inanimate

The closer to the left end of the scale an element is, the more likely it is to accept variation in number. In Corbett's terms (2000: 56), this diagrammatic representation means that the singular - plural distinction in a given language must affect the leftmost segments of the hierarchy.

Yet, the morphological behaviour of common nouns described here is still not given satisfactory explanation in terms of degrees of animacy. Therefore, they need to be overlaid by constraints resulting from the Definiteness Hierarchy (henceforth, DH; see Filimonova 2005: 79), which is another concept with a scalar character. It has been devised to calibrate the probability of certain morphosyntactic phenomena according to the quantifying force of nominal items or their readiness to serve as topics (hence the alternative label - givenness hierarchy).

(13) Personal Pronoun $>$ Proper Noun $>$ Definite $>$ Specific $>$ Non-Specific

This conceptual tool enabled linguists to deal successfully with, among other things, Differential Object Marking (Company Company \& Cuétara Priede 2008: 305-308; Schwenter 2014: 244-248; García García 2014) and case marking (Croft 1988: 163-164), etc. Here, its assumptions are going to be extended so that it shows how particular classes of nominal elements might vary in number: the higher the position of an item on the scale is, the more likely it is to evince singular vs. plural contrast. The DH demonstrates that non-specifically used NPs are the least favourable locus for variation in number to manifest itself. In what follows, the mechanisms responsible for inflection-meaning mismatches in distance-pole texts are construed as resulting from the interplay of the two hierarchies outlined above.

A concurrent application of the two scales leads to mutually exclusive predictions about inflectional behaviour of certain classes of expressions. In accordance with the criteria stated in the $\mathrm{AH}$, human-denoting nouns are moderately likely (or, at least, not unlikely) to inflect for number. Yet, all of them are used non-specifically in legal codices. According to what 
is found in the $\mathrm{DH}$, their non-specific status entails a reduced likelihood that variation in number will apply. What is being dealt with here is known as competing motivations (Croft 2003: 64-66). They are posited for explanatory purposes and rely on two claims: there are at least two motivations at work (M1 and M2) and M1 and M2 are in conflict (Mendívil-Giró 2003: 208-210).

The mechanisms underlying morphology-semantics mismatches in OS codices are assumed to be best approached in terms of a clash between the AH and the DH. Since the general desiderata they formulate cannot be satisfactorily fulfilled at once, a solution is needed. One of the possible typological scenarios, ${ }^{4}$ called override (Moravcsik 2014: 3-4, 6), has the following structure:

(14) apart from M1 (AH), which predicts the property A (human-denoting nouns do inflect for number) and excludes the property B (human-denoting nouns do not inflect for number), there is also M2 (DH), whereby $\mathrm{B}$ (human-denoting nouns do not inflect for number) is predicted and A (human-denoting nouns do inflect for number) is excluded. The solution is that M1 is superseded by M2, and the property B is the only outcome.

Rather than blindly following the constraints resulting from the $\mathrm{AH}$, particular number values surface according to the position of nominal items along the scale posited in the DH. The preference given to the second hierarchy in OS codices is nearly absolute. Yet, two important exceptions have to be pointed out. As said above, kinship terms have clear-cut attestations of syntax-independent plural forms. The second exceptional group involves the names of individuals professionally connected to the medieval Spanish judicial system.

\section{Concluding remarks}

The characterization of the inflectional status of common nouns denoting humans in OS legal texts is crucially dependent on how paradigms are defined. Amid a variety of approaches (see Corbett 2007: 11-12 for their concise summary), of special relevance are those where morphological constructs are given definitions taking into account other levels of linguistic analysis. In such methodological stances, paradigms are not construed simply as firmly established grids characterising 'lexemes' (or 'lexical units'). Instead, they owe their existence to the mapping of some communicatively relevant properties onto textual realizations of inflectional forms. To mention but one example of such an interface-based perspective on inflection, G. Gross's lexicon-grammar can be evoked. In this framework, it is distributional properties of lexical units that delineate their particular meanings and allot each of them to a separate paradigm.

Customary approaches to conjugation, by means of describing verbal paradigms (e.g., l'Art de Conjuguer de Bescherelle), strongly overrate the regularity of verbal inflection. Indeed, not all of the verbs have all tenses

4 Three other scenarios envisaged by Moravcsik involve: separation, compromise and deadlock. All of them share the following formula: 'In addition to M1, which predicts A and excludes B, there is also M2, which predicts B and excludes A'. The first scenario takes place if the domain of M1 and M2 splits: each yields its own structure A and B respectively, with each principle overriding the other in a separate domain. The conflict is settled by compromise if the content of both M1 and M2 is accommodated within a single structure that is similar to but not the same as A or B. Finally, for want of a constructive settlement, the clash results in a stalemate: neither M1 nor M2 fits. A completely new structure, unrelated to M1 or M2, is devised to replace the internally-conflicted motivations. 
or all moods. The oft-quoted example is the verb gésir. But it is far from being the unique type. In point of fact, the verb regarder 'to watch' fails to appear in compound past in two of its previously mentioned uses: ?Cela a regardé Luc 'It has concerned Luc', ?Le clocher a regardé la falaise 'The steeple was opposite the cliff'. [...] Thus, it becomes obvious that defectiveness can only be dealt with seriously if verbal uses are taken into account. It is not verbs that lack some of the inflectional forms for tense or for mood. Instead, it is a given use there of that fails to exhibit them' (Gross 1998: 106; emphasis - M.N. $\&$ M.T.). ${ }^{5}$

In the case of Spanish medieval codices, some of these properties arise in syntax, too. Conditional protases provide a suitable setting for morphology - semantics mismatches insofar as they specify a potential domain of application of universal deontic judgements. States of affairs that are merely hypothetical are, thus, paired with non-specific NPs. Such syntactic environments minimize the likelihood of common nouns surfacing as inherent plurals.

Aside from purely grammatical mechanisms, changes in the inflectional behaviour of some classes of common nouns can be triggered by text genre characteristics. Indeed, an important reason for the primacy of singular over plural forms is to be sought in the public relevance and the peculiar construal of legal regulations. Individuals subject to norms are conceived of as distributively represented sets. Rather than being extended at once to all persons who happen to have committed a specified kind of infringement, the norm is designed to come to grips with individual and separate cases. No wonder, if the singular is given preference over the plural, that each culprit is to be dealt with individually.

\section{References}

Booij, Geert. 1996. Inherent versus contextual inflection and the split morphology hypothesis. In Booij, Geert \& van Merle, J (eds.), Yearbook of Morphology 1995, 1-16. Dordrecht: Kluwer Academic Publishers.

Company, Concepción. 1991. La extensión del artículo en el español medieval. Romance Philology 44(4). 402424.

Company Company, Concepción \& Cuétara Priede, Javier. 2008. Manual de gramática histórica. México DF: Facultad de Filolofía y Letras - Universidad Autónoma de México.

Corbett, Greville G. 2000. Number. Cambridge: Cambridge University Press.

Corbett, Greville G. 2007. Canonical typology, suppletion, and possible words. Language 83(1). 8-42.

Croft, William. 1988. Agreement vs case marking in direct objects. In Barlow, M. \& Ferguson, Ch.A. (eds.), Agreement in Natural Language: Approaches, Theories, Descriptions, 159-180. Stanford: Center for the Study of Language and Information.

Croft, William. 2003. Typology and Universals. 2nd edition. Cambridge: Cambridge University Press.

Dryer, Matthew S. 2013. Coding of Nominal Plurality. In Dryer, M.S. \& Haselmath M. (eds.), The World Atlas of Language Structures Online. Leipzig: Max Planck Institute for Evolutionary Anthropology. http://wals.info/ chapter/33. (Accessed on 2016-07-01.)

Filimonova, Elena. 2005. The noun phrase hierarchy and relational marking: problems and counterevidence. Linguistic Typology 9(1). 77-113.

García García, Marco. 2014. Differentielle Objektmarkierung bei unbelebten Objekten im Spanischen. BerlinBoston: DeGruyter.

Gross, Gaston. 1998. Pour une véritable fonction "synonymie" dans un traitement de texte. Langages 131: 103114.

Haspelmath, Martin. 1997. Indefinite Pronouns. Oxford: Oxford University Press.

5 The verb gésir ('to lie, to be in a horizontal position') is traditionally held to provide a canonical example of verbal defectiveness in French; on the other hand, much in the same vein, regarder is quoted as a perfectly regular verb with a complete paradigm. 
Heim, Irene R. 1982. The Semantics of Definite and Indefinite Noun Phrases (2011 Edition). Ph.D. University of Massachusetts. http://semarch.linguistics.fas.nyu.edu/Archive/jA2YTJmN/Heim\%20Dissertation\%20 with\%20Hyperlinks.pdf. (Accessed 2015-06-14.)

Kibort, Anna. 2010. Towards a typology of grammatical features. In Kibort, Anna \& Corbett Greville G. (eds.), Features: Perspectives on a Key Notion in Linguistics, 64-106. Oxford: Oxford University Press.

Koch, Peter \& Oesterreicher, Wulf. 2001. Langage parlé et langage écrit. In Holtus, G. \& Metzeltin, M. \& Schmitt Ch. (eds.), Lexikon der Romanistischen Linguistik (LRL), 584-627. Band I/2. Tübingen: Max Niemeyer Verlag.

Koch, Peter \& Oesterreicher, Wulf. 2011. Die einzelsprachlichen Merkmale des gesprochenen Französisch, Italienisch und Spanisch in diachronischer und synchronischer Perspektive. In Koch, Peter \& Oesterreicher, Wulf. (eds.), Gesprochene Sache in der Romania: Franzözisch, Italienisch, Spanisch, 135-272. Berlin-New York: De Gruyter.

Labelle, Marie. 2001. Trente ans de psycholinguistique. Revue québécoise de linguistique 30(1). 155-176.

Lindschouw, Jan. 2013. Evolution and Regrammation in the Mood System: Perspectives from Old, Middle, Renaissance and Modern French. In Arteaga, D.L. (ed.), Research on Old French: The State of the Art, 123-148. Springer: Dodrecht.

Longobardi, Giuseppe. 1988. I quantificatori. In Renzi, L. (ed.) Grande Grammatica Italiana di Consultazione I, 645-696. Bologna: Il Mulino.

Mendívil-Giró, José Luis. 2003. Gramática Natural. La Gramática generativa y la tercera cultura. Madrid: Editorial A. Machado Libros.

Moravcsik, Edith. 2014. Introduction. In Moravcsik, Edith \& MacWhinney, B \& Malchukov, A. (eds.), Competing Motivations in Grammar and Usage, 1-14. Oxford: Oxford University Press.

Nkollo, Mikołaj, Wielgosz, Małgorzata. 2014. El recíproco ‘uno a otro' y sus variedades en el español medieval: Un estudio evolutivo. Romance Philology 68(2). 339-368.

O'Grady, William. 2011. Interfaces and Processing. Linguistic Approaches to Bilingualism 1(1). 63-66.

Penny, Ralph. 2002. A History of the Spanish Language. Cambridge: Cambridge University Press.

Schwenter, Scott A. 1999. Pragmatics of conditional marking: implicature, scalarity and exclusivity. New YorkLondon: Garland Press.

Schwenter, Scott A. 2014. Two kinds of differential object marking in Portuguese and Spanish. In Amaral, P. \& Carvalho, A.M. (eds.), Portuguese-Spanish Interfaces. Diachrony, synchrony, and contact, 237-260. Amsterdam-Philadelphia: John Benjamins.

Squartini, Mario. 2010. Where mood, modality and illocution meet: the morphosyntax of Romance conjectures. In Becker, M.G. \& Remberger, E.-M. (eds.), Modality and Mood in Romance. Modal interpretation, mood selection and mood alternation, 109-132. Berlin-New York: De Gruyter.

Topolińska, Zuzanna. 1977. Wyznaczoność (tj. charakterystyka referencyjna) grupy imiennej w tekście polskim. Argumenty niescharakteryzowane, grupy generyczne. Polonica III. 59-78.

\section{Corpora}

Gago Jover, Francisco (ed.). 2013. Digital Library of Old Spanish Texts. Hispanic Seminary of Medieval Studies - Spanish Legal Texts. www.hispanicseminary.org/t\&c/lex/index-en.htm. (Accessed 2015-10-21.)

The Cantar de mio Cid (Cid). 2015. Liberal Arts ITS, University of Texas at Austin. http://miocid.wlu.edu. (Accessed 2015-10-20.) 
